\title{
Ukrainian Literary Contest as an Opportunity for an Author: the Results of Survey in 2019-2020
}

\author{
Olha Bondar \\ Department of Public Relations and Journalism, Ukrainian Academy of Printing, Lviv, Ukraine
}

Email address:

olga.viktorovna.bondar@gmail.com

\section{To cite this article:}

Olha Bondar. Ukrainian Literary Contest as an Opportunity for an Author: the Results of Survey in 2019-2020. Humanities and Social Sciences. Vol. 8, No. 6, 2020, pp. 200-208. doi: 10.11648/j.hss.20200806.15

Received: December 12, 2020; Accepted: December 21, 2020; Published: December 31, 2020

\begin{abstract}
In this study, it was analyzed and published the results of a survey of 193 Ukrainian authors about how the literary contest contributes or does not contribute to their writing career. Famous and potential writers from different regions of Ukraine were asked to fill out a questionnaire and answer questions about the literary contest. The basic indicators for identifying respondents as authors were the availability of published or unpublished works. For both groups of authors, famous and unpublished, the number of winnings and the number of attempts to win were counted. It was found that it is usually difficult for an unknown author to find their first publisher and to collaborate about the subsequent publication of the book. In such circumstances, the professional judges of the literary contest, by reviewing the submitted creative works, preliminary evaluate their probable success. The results showed that the literary contest gives new authors some opportunities to be published, but less than they expect. Thus, it was found out that the Ukrainian literary contest is similar in its functions to a literary agent. Other functions of the literary contest were singled out, namely psychological, motivational, marketing, promoting, developing, and consecration. Of the functions of the Ukrainian literary contest, offered to the respondents, one took a dominant position discovering the new names of writers. "Koronatsiya slova" was named the most authoritative literary contest in Ukraine. The authors were also asked to note what the Ukrainian literary contests need. The answers demonstrate, that the difference between their expectations and the real possibilities of the contest is explained by the problems, which were grouped from the comments of the interviewed authors. The answers of the authors are recommended to be supplemented in the future by the answers of the representatives of the publishing houses and literary criticism.
\end{abstract}

Keywords: Literary Contest, Ukrainian Author, Submitted Works, Ukrainian Literary Field, Ukrainian Literary Contest, Unknown Authors, Book Market, Literary Prize

\section{Introduction}

The Ukrainian literary field and the book production industry are characterized by the slow development and the periodical stagnation, caused by some crisis political and economic events, which have befallen Ukraine during the relatively short time of its independence. And the government, instead of supporting the Ukrainian books, mostly hinders the survival of the publishing field by its decisions [1]. This situation is further enhanced with such reasons: publishers mostly do not operate with a large amount of money and do not get weighty financial support from sponsors, so they must make careful choices which author to publish and which to refuse; for many authors, the writing is rather a hobby, on which they spend free time from the full-day work - this work is often not related to the literary field (unlike European and American writers) - that certainly obstructs to improve their writings skills and to create the noticeable works [2]; and the reading has become a social problem [3]. So the publishers give access to the literary field and they choose the potential successful authors and novels for publishing, and success of their choices is confirmed by the consecration authorities (critics, prizes, book ratings), and it all causes the domination of the certain circles of writers. In such circumstances, the literary contest becomes an "unauthorized" entrance in the Ukrainian literary field for unknown authors or little-known ones. In this article, the results of the survey named "Authors and a literary contest" are presented; the purpose of this survey is to find out if the literary contest gives the chances for new authors to 
enter in the Ukrainian literary field, if it gives the famous authors the market advantages, and also how the authors are disposed to the contests.

\section{Theoretical Background}

In this section, the principles of selection of the respondents and the questions worded for the survey are argued, and also the definition, considered as the literary contest within this research, is explained. It is also important, that the survey will continue in the future, so the results provided in Section 3 should be considered like intermediate ones.

\subsection{Selection of Authors}

This survey aimed to study the role of a literary contest in the writer's career, so it needed to interview the famous and unknown authors. It had become the reason to start the survey on "Book Forum Lviv" in Lviv and to continue during the International Arsenal Book Festival in Kyiv - two annual international book festivals of Ukraine, which are visited by famous writers to meet their readers and followers, and unknown ones to offer their works to publishers. The first survey was conducted from the 19 of September to the 22 of September 2019 on "Book Forum Lviv" in Lviv. But because of COVID-19, it has become impossible to continue the survey on International Arsenal Book Festival in Kyiv, which was scheduled to take place in spring 2020. Therefore, an electronic form of a survey, based on Google Forms, was created and then shared on social networks and specialized groups of authors. In general, it was collected 206 questionnaires (offline and online), from which 193 were selected for the research. The respondents, which are not the authors - do not have any published works and any unpublished ones and do not consider the literary contest as an opportunity for promoting themselves and their oeuvre - were excluded from the selection.

\subsection{Literary Contest}

At the first stage of the survey with the individual interview of authors, which started in autumn 2019 within "Book Forum Lviv" festival, it had become clear that some authors do not understand the difference between the literary contest and the other related concepts such as a literary prize, a book prize, and a book rating. Thus, with a purpose to avoid semantic polysemy, it is reported to the authors before they fill the electronic form that the literary contest should be considered as "regularly or one-time competition, in which the professional judges elect one or few the best work from all unpublished ones, submitted to a contest personally by the authors, and which gives or does not give an award for winning" [4].

\subsection{Questions}

The survey consists of two types of questions - demographic ones, which allow making a slice by regions of residence, age and gender of the respondents, and special ones.

\subsubsection{Demographic Questions}

The authors are ranked by countries and regions of residence, gender, and four age categories: under the age of 26 , 27-35 years old, 35-45 years old, and over the age of 46 . Within this research, gender is not important, because the entrance in the literary contest is usually anonymous and gender may not affect judges' choices. However, distribution by sex allows rating the imbalance between the number of female authors and male authors, which submitted their works to the literary contests, and the number of winners of both genders.

\subsubsection{Special Questions}

The primary questions were: Do you have any published works? Do you have any unpublished works? Did you ever submit your work to any literary contest? Did you ever win in any literary contest? Do you consider the literary contest as an opportunity for promoting your oeuvre? Are you sure of the objectivity and impersonality of the jury? Are you sure about the clearness of the announced results of the contest? Would you submit the work to a contest, the rules of which require the entrance fees? What is the most prestigious literary contest in Ukraine?

The other questions were: What language do you write in? From which attempt have you won in the literary contest? How many winnings do you have? The authors were also offered to choose some functions of the literary contest, which, in their opinion, are relevant: filling the book market with quality works; promoting the Ukrainian language and Ukrainian author; discovering the new names of writers; is the means of advertising; researching conjuncture of book market; forming readers' preferences or none of the above.

The optional questions, which in full demonstrated how the famous and unknown authors are disposed to the contests, were: Why do the authors send their creative works to the contest? What do the Ukrainian literary contests lack? All quantitative indicators will be performed in detail in Section 3 of this article.

\section{Results}

\subsection{Demographical Slice of Respondents}

During fourteen months, from September 2019 to November 2020, it was collected 206 questionnaires, 193 of them were recognized as representative. There are 147 $(76.17 \%)$ women and $46(23.83 \%)$ men among the respondents. 57 (29.53\%) of them live in the Kyiv Region, 18 $(9.33 \%)$ - in the Lviv Region, $14(7.25 \%)$ - in the Poltava Region, $12(6.22 \%)$ - in the Cherkasy Region, 10 (5.18\%) - in the Kharkiv Region, 8 (4.15\%) - in the Vinnytsya Region, 8 $(4.15 \%)$ - in the Dnipropetrovs'k Region, $8(4.15 \%)$ - in the Ivano-Frankivs'k Region, $8(4.15 \%)$ - in the Chernihiv Region, 6 (3.11\%) - in the Zaporizhzhya Region, 6 (3.11\%) in the Khmelnytsky Region, 5 (2.59\%) - in the Rivne Region, $4(2.07 \%)$ - in the Volyn Region, $4(2.07 \%)$ - in the Donets'k Region, $4(2.07 \%)$ - in the Ternopil Region, 3 (1.55\%) - in the Zhytomyr Region, 3 (1.55\%) - in the Kirovograd Region, 3 
$(1.55 \%)$ - in the Kherson Region, $2(1.04 \%)$ - in the Mykolayiv Region, 2 (1.04\%) - in the Sumy Region, 1 (0.52\%) - in the Luhans'k Region, $1(0.52 \%)$ - in the Odesa Region, 1 $(0.52 \%)$ - in the Chernivtsi Region. 5 (2.59\%) interviewed persons are live in the others countries. There is no respondent from the Autonomous Republic of Crimea - the territory of Ukraine, which was annexed and occupied by Russia since 2014. Noticeable distance between the amounts of respondents from the Kyiv Region and other regions can be explained by the role of the capital city in the literary process many specialists from different regions always move on to the capital to find success.

However, the authors from the most "writing" regions do not win more often than authors from less "writing". It was checked how many authors represented a certain region and won literary contests. The results are shown in Table 1.

Table 1. Demonstration of the "writing potential" of the regions of Ukraine

\begin{tabular}{llll}
\hline Region of Ukraine & $\begin{array}{l}\text { Interviewed } \\
\text { authors, } \\
\text { persons }\end{array}$ & $\begin{array}{l}\text { Interviewed } \\
\text { winners, } \\
\text { persons }\end{array}$ & $\begin{array}{l}\text { Percentage of } \\
\text { winners, \% }\end{array}$ \\
\hline Kyiv Region & 57 & 33 & 57.8 \\
Lviv Region & 18 & 7 & 38.89 \\
Poltava Region & 14 & 11 & 78.58 \\
Cherkasy Region & 12 & 11 & 91.67 \\
Kharkiv Region & 10 & 3 & 30 \\
Vinnytsya Region & 8 & 4 & 50 \\
Dnipropetrovs'k Region & 8 & 4 & 50 \\
Ivano-Frankivs'k Region & 8 & 6 & 75 \\
Chernihiv Region & 8 & 6 & 75 \\
Zaporizhzhya Region & 6 & 4 & 66.67 \\
Khmelnytsky Region & 6 & 4 & 66.67 \\
Rivne Region & 5 & 2 & 40 \\
Volyn Region & 4 & 3 & 75 \\
Donets'k Region & 4 & 3 & 75 \\
Ternopil Region & 4 & 3 & 75 \\
Zhytomyr Region & 3 & 2 & 66.67 \\
Kirovograd Region & 3 & 2 & 66.67 \\
Kherson Region & 3 & 2 & 66.67 \\
Mykolayiv Region & 2 & 1 & 50 \\
Sumy Region & 2 & 1 & 50 \\
Luhans'k Region & 1 & 0 & 0 \\
Odesa Region & 1 & 0 & 0 \\
Chernivtsi Region & 1 & 1 & 100 \\
Autonomous Republic of & 0 & 0 & 0 \\
Crimea & & & \\
\hline
\end{tabular}

The authors are ranked by age categories: $35-45$ years old $65(33.68 \%), 27-34$ years old $-53(27.46 \%)$, over the age of $46-52(26.94 \%)$, and the smallest group consists of the persons under the age of $26-23(11.92 \%)$. This age distribution was done to confirm or deny the opinion, that the older the author is, the harder it is for him or her to debut and to obtain world fame: according to Danylenko, the main age of "entrance" in literature is before 30 years old, the second large group - from 30 to 45 years old [5]. This block of data shows, that active Ukrainian authors, the famous and the unknown, by age are in three groups, which by the number of representatives are about the same: $35-45$ years old - 65 (22 of them have no published works), 27-34 years old - 53 (15 of them have no published works), over the age of $46-52$ (10 of them have no published works). The smallest group consists of authors under the age of $26-23$ (16 of them have no published works). So, among future debutants (unpublished yet) are:

1) $69.57 \%$ of authors under the age of 26 ;

2) $33.85 \%$ of authors, aged $35-45$ years;

3) $28.3 \%$ of authors, aged $27-34$ years;

4) $19.23 \%$ of authors over the age of 46 .

Because the entrance in the literary contest is mostly anonymous, the age of entrant does not affect future winning, and the examples of famous world writers, mentioned by Danylenko in his monograph, are only a good illustration of how the literary process was done during the last century. However, in the context of the literary contest, there is a more important detail: the rules of some contests set age constraints. For example, Smoloskyp contest rules state that the entrants' age would be from 18 to 35 for poems and from 18 to 40 for prose ${ }^{1}$. Or Hranoslov contest rules state that the contest considers the works by citizens of Ukraine or foreign people over the age of 16 and under the age of $35^{2}$. And so the amount of available literary contests is limited for the authors over the age of 35 .

\subsection{Published and Unpublished Creative Works}

To find out which category the authors belong to - already famous or unknown yet - they were offered to answer two questions: do they have any published works and do they have any unpublished works? Authors were informed that the published works are the novels, essays, short stories, or poems published as a printed book.

The answers were distributed as follows: $130(67.36 \%)$ authors from 193 indicated that they have the published works. 125 of them have also unpublished works. 63 (32.64\%) authors from 193 specified that they have no published works. 57 of them have unpublished works. 188 (97.41\%) respondents write in Ukrainian, 141 (73.1\%) - only in Ukrainian, in Ukrainian and other languages: 46 (23.83\%) in Russian, 9 (4.66\%) - in English, and 3 (1.55) - in another language. 5 (2.59\%) persons write only Russian.

The first category represents authors, famous at least by one published book. We cannot rate the literary prestige of these authors, an important indicator of which is, according to Mark Verboord, "the literary reputation of the author's publishing house" [6]. This indicator is particularly significant given the fact that Ukrainian authors often publish their books at their own expense - this phenomenon was emerged in the Soviet Union and named "samizdat" - and as a result, they have no reputation of their publishing house at

1 See, e.g., Literary Contest organized by Smoloskyp, available at http://www.smoloskyp.org.ua/umovy-uchasti (last visited December 5, 2020).

2 See, e.g., Hranoslov Youth Literary Contest organized by National Writers' Union of Ukraine, available at https://nspu.com.ua/konkursi-i-premiji/ogoloshuietsya-prijom-robit-na-mizhnarod nij-molodizhnij-literaturnij-konkurs-granoslov-2020 (last visited December 5, 2020). 
all. However, within this study, it is important the fact, that the first official meeting of an author with his or her publisher and their reading audience already had happened. The presence of unpublished novels, essays, short stories, or poems indicates the active writing lives of these authors who weighed all advantages of book production and decided to continue creating the literary works.

The second category is more interesting in the context of the literary prize - the authors who have no published works yet, but they have the unpublished ones and, probably, looking for their first publisher. In this research, these 6 persons, who mentioned that they have no published and unpublished works, were counted as the potential authors, because they consider the literary contest as an opportunity for promoting their oeuvre, and so - they intend to create cultural goods.

\subsection{Authors and the Literary Contest}

The relationship between an author and a literary contest is directly characterized by the block of questions about his or her experience in a literary competition. Authors were explained, that the winning is a taking a prize place, declared in contest statute - receiving the title of contest laureate. And thus within this research, placing on a shortlist of finalists and receiving the encouraging rewards and diplomas are not considered as the winnings.

So $163(84.46 \%)$ authors from both categories - famous and unknown - stated, that they submitted their works to literary contests:

1) 113 of them won at least once;

2) 76 of them won with the first attempt;

3) 74 of them won several times.

122 of these 163 authors, who submitted their works to the literary contest, have the published works, so to belong to the first category of authors:

1) $95(77.87 \%)$ of 122 won at least once;

2) $63(51.64 \%)$ of 122 won with the first attempt;

3) $63(51.64 \%)$ of 122 won several times.

Unfortunately, the survey does not allow revealing, whether the winning in the literary contest is preceding the author's first publication, or is following it - this will be taken into account for further studies.

The most interesting is the category of the unpublished authors, from which 41 persons submitted he or she works to the literary contests at least once:

1) $18(43.9 \%)$ of 41 won at least once;

2) $12(29.27 \%)$ of 41 won with the first attempt;

3) $11(26.83 \%)$ of 41 won several times.

A key moment for the category of the unpublished authors is the fact that the winning or several winnings in the literary contests has no leads to an actual publication. The survey data show that the famous authors $(77.87 \%)$ win more often than the unknown ones $(43.9 \%)$. However, we have no data about whether the authors were famous when they won the first time and whether this winning contributed to the fact that these authors became famous.

37 authors from both categories reported that they won with not the first attempt. These authors were offered to point with which attempt they won. The minimum number of attempts was 2, maximum - 16. The total number of attempts for 37 authors is 144 . The average number of attempts to win per author is 3.9 .

74 authors from both categories reported that they won several times. They were offered to point how many times they won. The minimum number of winnings was 2, maximum -21 . The total number of winnings for 74 authors is 328 . The average number of winnings per author is 4.43 .

\subsection{The Degree of Confidence of Authors in the Literary Contests}

$177(91.71 \%)$ of all interviewed authors consider the literary contest as an opportunity for promoting themselves and their oeuvre, 121 of them are the published authors, 56 are the unpublished ones. But at the same time, some of them have doubts about the objectivity and impersonality of the jury and the clearness of the announced results of the contest. During the offline survey, there was an opportunity to communicate with authors, and it had become clear that the offered short answers "yes" and "no" are not enough, because authors' confidence depends predominantly on the contest and the current team of judges. So they believe in the justice of some literary contests, but do not believe the other ones. Therefore, the answer "depends on the contest and the jury" was added to the electronic form.

According to this survey block, 60 (31.09\%) respondents are sure of the objectivity and impersonality of the jury, 23 $(11.92 \%)$ are not sure. $110(56.99 \%)$ authors are sure or are not sure, depending on the current team of judges. 73 $(37.82 \%)$ authors are sure of the clearness of announced results, $18(9.33 \%)$ are not sure. $102(52.85 \%)$ authors are sure or are not sure, depending on the contest.

I was especially interested in the answers of the authors who did not win in the literary contest because ignoring their works by judges could affect their degree of confidence. So, 80 of the famous and the unknown authors pointed out that they had not won in literary contests:

1) 20 of them are sure of the objectivity and impersonality of the jury;

2) 16 of them are not sure of the objectivity and impersonality of the jury;

3) 41 of them are sure or are not sure, depending on the current team of judges;

4) 25 of them are sure of the clearness of announced results;

5) 12 of them are not sure of the clearness of announced results;

6) 40 of them are sure or are not sure, depending on the contest;

7) 30 of them did not submit their works to the contest.

The requirement of the entrance fees, that it must be paid by the author for participation, can reduce confidence in the literary contest. Of course, contest organizing needs costs, at least for information support, fees to jury members and involved stuff, payment of awards, if it is provided. However, 
the requirement of the entrance fees makes the literary contest a type of "prize gaming", which incorporates gambling, sweepstakes, and contests, including literary ones, in which the participants pay money for the chance to win something - but "a contest differs from gambling only because the winner is determined primarily by skill as opposed to chance" [7]. It is interesting, that in some states of the USA the creative contests, which require the entrance fees for participation, are considered as sweepstakes, whether the winners use their skills to win or hope on chance [8].

Some Ukrainian literary contests collect entrance fees, arguing that in this way the authors' serious intentions are checked and the "graphomaniacs" are excluded. For example, The rules of the contest named "Write the book about me" state that "aimed to receive from the authors the works, more quality prepared, and to separate random manuscripts at the first stage, we have introduced the entrance fees - 100 UAN for the "Good fairy tales" nomination and 200 UAN for the "Good adventures" and "Book about me" nominations". Organizers explained that this requirement will encourage the authors a more responsible attitude to writing ${ }^{3}$. This argument, in my opinion, is not confirmed, because this requirement, on the contrary, estranges the serious authors who create the quality texts and do not want a "paid" winning. There are also contests, which have considered the authors' creative works for many years and did not require the entrance fees, but then they have changed their organizational policy. For example, Smoloskyp contest rules state "Participation in the contest is possible only if you donate at least $300 \mathrm{UAN}^{\prime 4}$. Until 2018, participation in this contest was free.

Ukrainian scientists did not pay attention to this problem, but the literary contest, rules of which require the entrance fees, is losing its consecration authority. And for the authors from developing countries, this requirement is sometimes becoming an insurmountable obstacle. 115 (59.59\%) authors pointed that they would not submit their works to the literary contest, the requirement of which is the entrance fees. But for $78(40.41 \%)$ authors this requirement does not matter.

\subsection{The Most Popular Ukrainian Literary Contest}

Authors were offered to name a literary contest, which, in their opinion, is the most authoritative. There are relatively few authoritative, popular, and regular literary contests in Ukraine. However, we did not example a list of them, from which one could choose, to avoid imposing a decision. So, the authors could indicate that contest or a few of the contests, which had come to mind first, - the number of contests was not limited. According to the results of this block of questions, the literary contest mentioned the most, is "Koronatsiya slova", $-157(81.35 \%)$ authors recognized it

3 See, e.g., Literary Contest "Write the book about me" organized by the publishing "Fontan kazok", available at http://fontan-book.com/nashi-aktsiyi/literaturnyj-konkurs-napyshit-pro-mene-kny zhku-p-yatyj-sezon-2019 (last visited December 4, 2020).

4 See, e.g., Literary Contest organized by Smoloskyp, supra note 1.

5 International Literary Contest "Koronatsiya slova", available at as the most authoritative. However, 17 (8.81\%) authors think, that there is no one authoritative literary contest in Ukraine. With a significant gap from the "Koronatsiya slova" the Literary contest of Smoloskyp publishing house was pointed $-9(4.66 \%)$ voices. And the Hranoslov ${ }^{6}$ had received only 3 $(1.55 \%)$ voices. Literary contests, which have received less than 1 percent of voices, were not illustrated here, because their information support is not enough for the promotion of authors.

Despite the definition of the literary contest, given at the beginning of the survey, $6(3.11 \%)$ authors pointed the Shevchenko National Prize and $3(1.55 \%)$ authors noted the BBC Book of the Year (and some others, which received only one voice) - they are not a literary contest by definition, but a book prize. Book prizes do not evaluate the unpublished works and are not able to give the market advantages to the unknown yet author [4]. The scientific discussion needs to eliminate semantic polysemy because the definition elucidates the functions, which is different for the literary contest and the book prize.

\subsection{Functions of the Ukrainian Literary Contest}

The Ukrainian literary contest combines functions of a literary agent and the consecration authority, at the same time allowing the unknown authors to declare themselves and the already famous authors to receive the market advantages. Authors were offered to mark the functions of a literary contest, which, in their opinion, it has. The answers were distributed as follows:

1) discovering the new names of writers - $169(87.56 \%)$ persons;

2) promoting the Ukrainian language and Ukrainian author -147 (76.17\%) persons;

3) filling the book market with quality works -83 (43.01\%) persons;

$4)$ is the means of advertising - 75 (38.86\%) persons;

5) forming readers preferences - 60 (31.09\%) persons;

6) researching conjuncture of book market - 44 (22.8\%) persons;

7) none of the above $-3(1.55 \%)$ persons.

\subsection{Why Do the Authors Submit Their Creative Works to Contest}

102 authors answered this optional question with enthusiasm and in the form of short comments. It is also worth considering, that the authors may not be familiar with publishing and all related processes. Their answers are their subjective reflections on the potential of the literary contest in their writing career. Here are the statements of the respondents grouped by meaning, which will be supplemented with the publishers' and the literary critics' answers in future research. The authors were not limited to the number of responses.

The largest group of statements is related to effective

http://koronatsiya.com (last visited December 5, 2020).

6 Hranoslov Youth Literary Contest, supra note 2. 
author's communication with the publisher - we have 84 $(82.35 \%)$ responses. So, first of all, authors submit their works to a literary contest to find publishers and propose them cooperation, the result of which must be the published book at the expense of the publisher. Such expectations can be explained by the fact that authors send their works to the e-mail addresses of publishing houses (often the same literary works as in the contest), but rarely have responses - neither approval nor refusal. This fact, of course, speaks more about the culture of the publishing house, than about the problems of the book production field. So, a literary contest such as Smoloskyp, organized by a publishing house, or a literary contest such as "Koronatsiya slova", with the publishers as judges, - this is an opportunity for the author to be noticed by the publisher who ignored his or her work among the official correspondence. For the reason that the literary contest allows authors to declare of them and to start their writing careers, we can talk about the noticeable functions of a literary agent.

The second large group of statements suddenly demonstrates the importance of the psychological function of a literary contest - we have $44(43.14 \%)$ responses. So, the authors submit their works to the literary contest to satisfy their needs for recognition, fame, creative realization, development, and also to increase their self-esteem and to believe in themselves, find their purposes, share their stories, and to be heard. $12(11.76 \%)$ of them reported a competitive spirit and the desire to win.

Both the unknown and the famous authors submit their works to the literary contest to promote their oeuvre and books - for example, by adding the label "winner of the contest" to cover - and also with aimed to find or expand their readership. It indicates the marketing and advertising functions of the literary contest - we have 25 (24.51\%) responses. After all, as James English says, the received award is a cultural value, which can be exchangeable for another form of capital [9].

According to $23(22.55 \%)$ responses from the last large group, the literary contest can be characterized as the motivation for the professional growth of writers. The authors submit their works to test themselves and to check the level of their skills, by receiving reviews of literary authorities, from which the professional jury is completed. So the authors can take into account comments and feedback and improve their writing skills, get inspiration from new accomplishments. However, it should be explained, that the judges of many Ukrainian literary contests do not comment on the submitted works and do not communicate with the authors - the contest rules usually inform about it. Some literary contests, such as Smoloskyp, review the submitted manuscripts on request and at an additional cost. For example, Smoloskyp contest rules state that "texts are not returned and are not reviewed publicly"7. However, the author, who had submitted his or her work, can receive the review of the contest team, on personal request and at an additional cost.

7 Literary Contest organized by Smoloskyp, supra note 1.
The authors also gave single answers, which cannot be grouped because of a small number, but these opinions have not to be without our attention. So, the authors submit their works to the literary contests to get money (7 responses), to come into the literary field (4 responses), and because they have no idea what to do with their creative works (2 responses).

\subsection{Problems of the Ukrainian Literary Contests}

The literary contest has functions, which are important for both the literary field and the book production industry. The realization of these functions is limited by certain problems. The second optional question was about what do the Ukrainian literary contests lack. In my opinion, this question is very important, because the answers made it possible to formulate not theoretical problems of the literary contest in the scientific context, but real problems faced by the authors.

Answers, sometimes expressive, were not limited by the number and were given by 79 authors in the form of short texts. For this reason, these responses were also grouped. So, such problems of the Ukrainian literary contests were stated through the eyes of the direct participants:

1) $25(31.65 \%)$ persons think that the literary contests lack the professional ${ }^{8}$, objective, and impersonal judges who would not represent the interests of certain authors or societies of authors, including for a fee

2) $21(26.58 \%)$ persons need feedback, reviewing the submitting works, constructive criticism, and detailed information about contests ${ }^{10}$;

3) $20(25.32 \%)$ persons suppose that the literary contests are not heavily advertised on all stages - from the announcement about the start of submitting to award ceremony;

4) $19(24.05 \%)$ persons observe a low quality of the winners' works, its thematic sameness and irrelevance, conjuncture and ignoring trends;

5) $19(24.05 \%)$ persons realize ineffectiveness in further publishing and promotion of the winners' works ${ }^{11}$;

\footnotetext{
8 However, in contrast to the desire to see the professional judges, which consists of employees of the literary industry, it was also expressed an opinion on the need for a non-professional readership jury $(1.27 \%)$ because the reader is the end consumer of a literary work.

9 It is worth noting, that it is impossible to exclude the factor of judges' subjectivity, but this factor is intensified by the unprofessionalism of experts, for example, the students of literary specialties, who, despite their erudition, have no professional experience. The same can be said for judges-publishers, who often have no literary specialty and use the commercial indicators of a manuscript for evaluation - and often lobby the interests of their "home" writers. It is also suspected that some members of the jury do not read the submitted works at all $(6.33 \%)$.

10 Authors can take information about submitting mostly from the official sites of contests and their network pages if they visit those pages themselves. Authors often learn about the contest when already the results were announced. They also often have no connection with organizers, because the contacts of the contest often are not available.

11 Authors also reported about disadvantageous terms of the contract with a publisher as a result of winning $(2.53 \%)$, such as no fee, the requirement to change the text (in whole or in part), or grant all its copyright. It is necessary to explain, that the literary contests such as Koronatsiya slova, organized by not publishers, are not related to further negotiations between the author and the publisher.
} 
6) $16(20.25 \%)$ persons consider at a problem the insufficient sponsorship and also ignoring cultural events by the government;

7) $16(20.25 \%)$ persons emphasize a small number of literary contests, in particular, the novel contests;

8) $14(17.72 \%)$ persons noted the lack of the clear and fair criteria of selection and evaluation, announced and directed on an aesthetic component, but not commercial or patriotic ones;

9) $12(15.19 \%)$ persons informed that the already famous authors win more regularly than unknown ones, and the judges do not often risk to select a new author;

$10) 9(11.39 \%)$ persons would like to get a more worthy monetary reward ${ }^{12}$

$11) 9(11.39 \%)$ persons noted the lack of genre nominations and mono-genre contests, such as detective stories contest, fantasy contest, etc., and observe bias of some genres in the poly-genre contests $^{13}$

12)7 (8.86\%) persons raised an issue of breach of obligations, such as violating privacy data of participants or copyright law;

13)3 $(3.8 \%)$ persons would like the understandable and simple contest rules of the submission of the works, and the other $3(3.8 \%)$ persons need regularity.

This list can be added with single responses, for example, about the necessity to demonstrate the inner the selective process of the literary contest, non-trivial approach to the submitted works, nationalistic direction, equal distribution of the famous authors and unknown ones, freedom of speech and expression, longevity.

\section{Discussion}

In this study, the results of the survey of the famous authors and unknown ones about their experiences of interaction with the Ukrainian literary contests were analyzed. Their answers allowed us to single such statements out:

1. Be published is a leading reason for authors to submit their works to the literary contest. 63 authors noted that they do not have the published works. 57 (90.48\%) of them have unpublished works, including 56 persons who consider the literary contest as an opportunity for promoting their oeuvre. This is an audience, which actively (by submitting their works to the contests) are looking for a publisher. Many answers to the first optional question confirmed this thesis - we have 84 responses. Are the author's expectations satisfied in reality?

2. Winning does not guarantee to publish. So, from 113 authors who won at least once, 18 (15.93\%) persons do not have the published works -11 of them won several

12 In Ukraine, the monetary reward for winning is usually symbolic or is not given at all.

13 We are talking about the contests such as Koronatsiya slova, in which the works of many genres are considered, but the works of one certain genre usually win: for instance, the historical novels won the First Prize during 2017-2020. times. $19(24.05 \%)$ respondents noticed that the literary contest lack effectiveness in further publishing and promotion of the winners' works: winning and receiving the laureate title or the participant's diploma does nothing change - the author's work is not published or is not promoted. So, their expectations not fully matching: the authors submit their works to the contest to find a publisher (84) and to publish a book; however, this is mostly not received. The publishers refuse to publish winners' works usually for such reasons: 1) it is impossible to agree with the author on the editing and the amount of the fee, 2) low literary quality of the text and 3) bad reputation of a certain contest. However, there are many more refuses with direct contact between authors and publishers, so $15.93 \%$ - in is not the critical indicator.

3. Literary contest discovers the new names of writers. This function was marked by $87.56 \%$ of respondents. This is also confirmed by the fact that many Ukrainian writers became famous after winning a literary competition. So, for example, 144 "newborn" authors were opened by "Koronatsiya slova" as of 2013 [10]. An encyclopedia of popular literature, dedicated to the 20th anniversary of the contest, mentions that the "Koronatsiya slova" received about 80000 works (in all nominations) for 20 years [11]. It speaks about a large number of potential authors.

4. The first winning in the literary contest motivates to further achievements. Among 76 famous and unknown authors who won with the first attempt, 49 (64.47\%) won several times - it means they have continued to submit their works to the literary contests. Thus we can say about the motivational function of the literary contest, which stimulates writing activity. So the literary contests are very popular among both the famous authors and the unknown ones, and many of them regularly submit their works to the various contests' jury.

5. The high-quality work will find its publisher even without the literary contest. So, 130 authors have the published works, but 35 (26.92\%) of them have never won in the literary contest, including the 8 persons who did not submit their works. However, taking into account the attraction of the Ukrainian authors to "samizdat", we cannot be sure, that all these published out of the contest line authors have published their books in publishing houses and at the expense of publishers.

6. Famous authors use the literary contest for promoting themselves and their works. 130 authors marked that they have the published works - these are the writers, famous at least one book. $125(96.15 \%)$ of them also have published works, which means that they continue to write. 92 authors, who have both the published works and unpublished ones, won at least once, and 62 of them - won several times. Authors, who won several times, were asked to name the number of winnings. So, the total number of winnings for 62 authors is 285 , that are 
4.6 winnings per author. However, this is an average indicator, because the number of winnings, specified by a separate author, varies from 2 to 21.121 (93.08\%) authors from 130, who have the published works, marked that they consider the literary contest as an opportunity for promoting their oeuvre.

7. The literary contest is promoting the Ukrainian language and Ukrainian author. $76.17 \%$ of respondents recognize the role of national literary contests in the revival of the Ukrainian language. So the very important function for a postcolonial country stands out: promoting the Ukrainian language. During the dominant regimes of the Russian empire and the USSR, the Russian language was systematically and forcibly rooted, so even now, when Ukraine is an independent country, the part of citizen does not speak, read and write in Ukrainian. The language problem is still real because Russia uses the "word" as a weapon in the war against Ukraine [12]. So the literary contest, the judges of which consider only Ukrainian-language works, encourages the Russian-language authors to write in Ukrainian.

8. The effect of institutional inertia is observed. Authors reported about lack of fresh insights, freedom of expression, interest in the new genres, the fair process of selection, diversity. There is also conservatism of judges, the imposition of ideology, ignoring of new names, "nepotism" of jury and participants, orientation on military-patriotic themes - this is understood in conditions of the "Euromaidan" (2013-2014) and the war of Russian Federation against Ukraine (from 2014 till now) [13]. The statement of one of the respondents is especially revealing: "works, which were selected as laureates, remind the long-known plots, a little bit rewritten in a new way". All these are signs of institutional inertia. In the Ukrainian context, it is interesting, that a literary contest (and also a literary prize, a book prize, and a book rating) has not yet acquired the status of a literary institution [14]. The reasons for this fatal divergence require a separate scientific study.

9. Uneven distribution of participants of the literary competition is observed. 163 authors submitted their works, $74(45.4 \%)$ of them won several times (the total number of winnings for 74 authors is 328$), 50$ (30.67\%) of them did not win any time, and $39(23.93 \%)$ of them won with the first attempt. So, while $30.67 \%$ of authors did not win any time, $45.4 \%$ of authors received an average of 4.4 winnings. It can speak about the mentioned above institutional inertia, characterized by conservatism and ignoring new names, or about the improvement of authors' writing skills, who surpass themselves with each submitted to the literary contest work.

10. Women become winners of the literary contests as often as men. So, of the total number of respondents 126 women and 37 men submitted their works to the literary contests. From them, $88(69.84 \%)$ women and 25
$(67.55 \%)$ men won. Unlike a literary prize - for example, from 117 laureates of the Nobel Prize in Literature, only $16(13.68 \%)$ are women ${ }^{14}$, approximately the same number of male winners and female winners of the literary contests is explained by the fact that the jury usually judges the anonymous manuscripts. Thus, men do not write better than women. This indicator, probably, will be interesting for researchers of gender studies, because the mentioned fact proves uneven distribution of winners between men and women if their gender is known to the judges [15].

\section{Conclusion}

An analyzed survey shows, that the literary contest is not guaranteed, but a good chance to start a writing career for unknown authors. With the help of the authors, the common functions of the Ukrainian literary contest were indicated, such as communicative - the function, which in Europe and the USA deposited on the literary agents, - psychological, motivational, marketing, promoting, developing and consecrating.

The asked authors singled out only one widely known among the creative community Ukrainian literary contest - the "Koronatsiya slova". This is a critically small number within the whole country. There are other literary contests in Ukraine, but they usually have no power information support and therefore they cannot reach a wide audience. Some of them require entrance fees, and, as the survey shows, $59.59 \%$ of their potential participants ignore such creative contests for this reason. Authors also helped to describe some problems of the literary contest, and these problems mostly relate to general problems of the literary field and book production industry in Ukraine.

We will be able to talk about the full-functional potential of the literary contest when we will supplement this survey of authors with the survey of publishers, book distributors, and literary critics. Probably, the results of this survey and a common vision of problems of the literary contest will lead to their whole or in part elimination, and also will help the Ukrainian cultural fields in general.

\section{References}

[1] Demuz, I. O. (2014). National Book Market in the Context of Implementing the Humanitarian State Policy. University economic bulletin, 37 (1), 69-74. doi: 10.5281/zenodo.1220635.

[2] Parandowski, J. (1991). The Alchemy of the Word. Kyiv: Dnipro, 374. ISBN 5-308-00824-8.

[3] Ohar, E. (2014). Reading in the Structure of the Modern Cultural Practices (under the Materials of the All-Ukrainian Sociological Opinion Surveys). Scientific Notes of the Institute of Journalism, 55, 35-39.

14 The Nobel Prize in Literature, available https://www.nobelprize.org/prizes/literature (last visited December 5, 2020). 
[4] Bondar, O. (2019). Concept "Literary Prize": Problems of Description. Printing and Publishing, 2 (78), 117-125. doi: 10.32403/0554-4866-2019-2-78-117-125.

[5] Danylenko, V. (2008). The Lumberjack in the Desert: the Writer and the Literary Process. Kyiv: Akademvydav, 352. ISBN 987-966-8226-59-5.

[6] Verboord, M. (2003). Classification of Authors by Literary Prestige. Poetics, 31 (3-4), 259-281. doi: 10.1016/S0304-422X(03)00037-8.

[7] Cabot, A. N. and Csoka, L. V. (2003). The Games People Play: Is It Time for a New Legal Approach to Prize Games? Nevada Law Journal, 4, 197-261.

[8] Evers, P. S. (2010). Contests, Contracts and Copyright: Sometimes a Great CONtests. University of Denver Sports and Entertainment Law Journal, 34-45.

[9] English, J. (2005). The Economy of Prestige: Prizes, Awards, and the Circulation of Cultural Value. Cambridge: Harvard UP, 432. ISBN 978-0-674-03043-5 (pbk).

[10] Lohush, T., Lohush, Y. (2014). Contest "Koronatsiya slova": the Third Wave of Modern Ukrainian Literature. Contemporary
Ukrainian Fiction: the Coordinates of the "Koronatsiya slova", Mykolayiv: Ilion, 6-31. ISBN 978-617-534-239-8.

[11] Lohush, T., Lohush, Y. (2019). 20th Anniversary of the "Third Wave" of Modern Ukrainian Literature. "Koronatsiya slova": scientific-reference issue, Kyiv: Svit Uspihu, 20-31. ISBN 978-617-7324-34-7.

[12] Liebiedieva, Y. (2019). Russia's Hybrid Warfare against Ukraine in 1917-1921 and 2014-2019 and Ukrainian Governments' Activities for Overcoming the Results of the Aggression. Ukrainian Studies, 2 (71), 57-72. doi: 10.30840/2413-7065.2(71).2019.171753.

[13] Polishchuk, Y. (2016). Reactivity of Literature. Kyiv: Akademvydav, 192. ISBN 978-617-572-098-1.

[14] Hodgson, G. (2005). "Institution" by Walton H. Hamilton. Journal of Institutional Economics, 1 (2), 233-244. doi: $10.1017 /$ S1744137405210202.

[15] Demoor, M., Saeys, F., and Lievens, S. (2008). "And the winner is?" Researching the relationship between gender and literary awards in Flanders, 1981-2000. Journal of Gender Studies, 17 (1), 27-39. doi: 10.1080/09589230701838370. 